\title{
Availability of copper from phytoplankton and water for the bivalve Macoma balthica. I. Separation of uptake pathways using the radiotracer ${ }^{64} \mathrm{Cu}$
}

\author{
M. C. P. Absil ${ }^{1}$, J. J. Kroon ${ }^{2}$, H. T. Wolterbeek ${ }^{2}$ \\ 1 Netherlands Institute of Ecology, Centre for Estuarine and Coastal Ecology, Yerseke, The Netherlands \\ 2 Interfaculty Reactor Institute, University of Technology, Delft, The Netherlands
}

Received: 22 June 1993 / Accepted: 2 September 1993

\begin{abstract}
To study the role of food in $\mathrm{Cu}$ accumulation by bivalves, algae spiked with $\mathrm{Cu}$ can be used. With spiked algae, however, redistribution of $\mathrm{Cu}$ between the dissolved and the particulate phase hampers the assessment of the contribution of food. This occurred in efforts to label algae with the radiotracer ${ }^{64} \mathrm{Cu}$. A method was designed to overcome this problem of redistribution. By adding excess EDTA to seawater, the biological availability of dissolved $\mathrm{Cu}$ was minimized. The effectiveness of complexation by EDTA was controlled through adsorption on Macoma balthica shells and uptake in M. balthica tissue.
\end{abstract}

\section{Introduction}

The assessment of the contribution of different uptake pathways to the overall metal accumulation in aquatic organisms has been proven to be relatively difficult. Because of their feeding behaviour, they can be directly exposed to metals in the waterphase, as well as to foodassociated metals. For bivalves, some information is available on Cd accumulation via food (Borchardt 1985, Riisgård et al. 1987). On Cu accumulation, however, very little is known. An obvious reason for the scarcity of $\mathrm{Cu}$ data is the problem of assessing the bioavailability of different $\mathrm{Cu}$ species: when $\mathrm{Cu}$-contaminated particles are placed in clean water, a solute-solid equilibrium will be established. The distribution of $\mathrm{Cu}$ between the dissolved and particulate phase depends among other things on the ligand concentration in the solution ( $\mathrm{Cu}$ complexing capacity) (Zamuda and Sunda 1982, Gerringa et al. 1991). From the dissolved species, the free ionic form is considered the best biologically available (Crecelius et al. 1982, Zamuda and Sunda 1982, Sundra et al. 1984). The complex chemistry of $\mathrm{Cu}$ makes it difficult to assess the contribution of a particular species to the overall accu-

Communication number 644 of the Centre for Estuarine and Coastal Ecology, Yerseke, The Netherlands mulation. The objective of the present study was to design a method that would make it possible to study the dissolved and particulate $\mathrm{Cu}$ uptake route separately. To this end, we labelled algae with the radiotracer ${ }^{64} \mathrm{Cu}$ and used ethylenediaminetetraacetate (EDTA) to minimize the biological availability of dissolved ${ }^{64} \mathrm{Cu}$. The effectiveness of EDTA complexation was assessed in adsorption and uptake experiments with the bivalve Macoma balthica.

\section{Materials and methods}

${ }^{64} \mathrm{Cu}$ preparation and measurement

${ }^{64} \mathrm{Cu}$ was obtained by irradiating $3 \mathrm{mg}$ copper wire $(99.99 \%$; Ventron, Karlsruhe) for $24 \mathrm{~h}$ in the nuclear reactor of the Interfaculty Reactor Institute of the University of Technology, Delft, The Netherlands [the so-called Hoger Onderwijs Reactor (HOR); neutron flux $=10^{12}$ to $10^{13} \mathrm{~cm}^{-2} \mathrm{~s}^{-1}$ ]. Radioactivity of the wire after $24 \mathrm{~h}$ was 125 mega becquerels $(\mathrm{MBq}) \mathrm{mg}^{-1}$. The irradiated wire was dissolved in $25 \mu \mathrm{l}$ concentrated nitric acid and diluted in $50 \mathrm{mM}$ $\mathrm{Na}$-acetate buffer ( $\mathrm{pH}$ 5.6). The final $\mathrm{Cu}^{2+}$ concentration in the stock solution was $1 \mathrm{mg} \mathrm{ml}^{-1}$. The isotope has a half-life of $12.8 \mathrm{~h}$. By preparing this stock solution just before starting the experiment, we were able to perform measurements for at least $4 \mathrm{~d}$. The starting activity of a $30 \mathrm{nMCu}$ solution, spiked with ${ }^{64} \mathrm{Cu}$, was about $900 \mathrm{cpm}$ (counts per minute) $\mathrm{ml}^{-1}$. As a simplification, $\mathrm{Cu}$ solutions spiked with ${ }^{64} \mathrm{Cu}$ are further referred to as ${ }^{64} \mathrm{Cu}$ solutions.

${ }^{64} \mathrm{Cu}$ accumulation in Macoma balthica (collected from the Oosterschelde sea arm in November 1991) was followed by measuring radioactivity of dissected shells and tissue, or living individuals (whole bodies). To facilitate accurate dissecting after exposure, the individuals were quickly frozen and subsequently separated into shells and tissue. Samples (water, labelled algae, or $M$. balthica) were counted with the help of a NaI detector. Counting time was maximally $10 \mathrm{~min}$; counting error was $\leq 5 \%$. Corrections were made for background radioactivity, ${ }^{64} \mathrm{Cu}$ decay, and shell size.

\section{${ }^{64} \mathrm{Cu}$ uptake by phytoplankton (Expt 1)}

The diatom Phaeodactylum tricornutum was spiked with ${ }^{64} \mathrm{Cu}$. This $\mathrm{Cu}$-tolerant diatom species is often used as a food source for bivalves in experimental situations. It is able to continue to grow at 
Cu concentrations up to $8 \mu M$. Other reports also mention a relatively high survival and growth of $P$. tricornutum under $\mathrm{Cu}$ stress, compared with other phytoplankton species (Bentley-Mowat and Reid 1977). Strains from a batch culture in the late exponential phase (reared in outdoor tanks in enriched filtered seawater) were concentrated using a tangential flow membrane filtration system (Millipore). Further, they were resuspended in 2-litre polyethylene beakers in $0.45 \mu \mathrm{m}$ membrane filtered seawater (FSW, salinity = $34 \mathrm{~g} \mathrm{~kg}^{-1}$ ). The water contained 0.79 or $7.9 \mu M{ }^{64} \mathrm{Cu}$. The algae were allowed to grow for 24 to $48 \mathrm{~h}$ at room temperature under continuous Tube Light (Philips, $40 \mathrm{~W}$, colour no. 33). The algal culture was stirred gently with a magnetic stirrer.

After the uptake period, the ${ }^{64} \mathrm{Cu}$-labelled algae were concentrated by tangential flow flux and additional centrifuging for $10 \mathrm{~min}$ at $2000 \mathrm{~g}$. The algae were resuspended in a $5 \mu M$ EDTA solution in FSW in 50 -ml centrifuge tubes to remove the loosely bound ${ }^{64} \mathrm{Cu}$. After a rinsing period in the EDTA solution, varying between 1 and $24 \mathrm{~h}$, the algae were centrifuged and rinsed for $30 \mathrm{~min}$ in FSW. Concentrations of ${ }^{64} \mathrm{Cu}$ in the water and in the algae were measured by pipetting $5 \mathrm{ml}$ suspension on a $0.45-\mu \mathrm{m}$ filter (Nuclepore). Four $\mathrm{ml}$ of the filtrate were counted simultaneously with a 5 - $\mathrm{ml} \mathrm{unfiltered}$ sample. After volume correction of the samples, the difference in counts between the filtered and unfiltered sample, was considered to be the amount of ${ }^{64} \mathrm{Cu}$ that was adsorbed on the algae. A comparable method to assess radionuclide adsorption to algae was described by Fisher et al. (1983). A correction of $2 \%$ was made for ${ }^{64} \mathrm{Cu}$ retention by the filter from spiked water without algae. After centrifuging, the concentrated algae were resuspended in 1.5-litre volumes.

These spiking experiments were carried out to study the uptake and adsorption by Phaeodactylum tricornutum. The duration of the spiking period and the intensity of rinsing were varied in order to obtain the highest possible ${ }^{64} \mathrm{Cu}$ load and as little loss as possible of ${ }^{64} \mathrm{Cu}$ from the algae during resuspension in clean water.

\section{Complexation of ${ }^{64} \mathrm{Cu}$ by EDTA (Expt 2)}

As the labelled algae were leaking ${ }^{64} \mathrm{Cu}$ when resuspended in ${ }^{64} \mathrm{Cu}$ free FSW, this could seriously influence the outcome of uptake experiments with bivalves. By adding EDTA to the seawater, the biological availability of dissolved ${ }^{64} \mathrm{Cu}$ should be minimized. In several studies, EDTA has been shown to reduce the accumulation and toxicity of $\mathrm{Cu}$, indicating that the EDTA-Cu complex is less biologically available than the free $\mathrm{Cu}$ (Stephenson and Taylor 1975, Cheng 1979, Sundra et al. 1984).

The effectiveness of EDTA-complexation was examined by measuring adsorption processes on separate Macoma balthica shells. Adsorption into shells was used as a measure for the amount of "free" $\mathrm{Cu}$.

The theoretical concentrations of free and complexed $\mathrm{Cu}$ and EDTA were calculated with the chemical equilibrium program SOILCHEM (Sposito and Cobes 1988).

In a 1.5-litre volume of filtered seawater with ${ }^{64} \mathrm{Cu}$ and EDTA (Merck, Titriplex III p.a.), shells were allowed to adsorb ${ }^{64} \mathrm{Cu}$ for a period of $48 \mathrm{~h}$. At regular time intervals, the shells were taken from the medium and rinsed in FSW for a few seconds. The shells were transferred to glass vials and immediately counted. Adsorption kinetics were followed by measuring ${ }^{64} \mathrm{Cu}$ activity in four different situations: in the first, ${ }^{64} \mathrm{Cu}(31 \mathrm{n} M)$ and EDTA $(2.7 \mu M)$ were introduced together with Macoma balthica shells in the seawater. In the second, the shells were introduced $20 \mathrm{~h}$ after the introduction of ${ }^{64} \mathrm{Cu}(31 \mathrm{n} M)$ and EDTA $(2.7 \mu M)$. In the third, adsorption of $31 \mathrm{n} M^{64} \mathrm{Cu}$ without EDTA was measured. In the fourth situation, ${ }^{64} \mathrm{Cu}(310 \mathrm{n} M)$ and EDTA $(2.7 \mu M)$ were mixed together before they were introduced with the shells in the seawater.

In a further experiment, ${ }^{64} \mathrm{Cu}$ adsorption on shells and accumulation in tissue of living Macoma balthica in the presence of excess EDTA $(270 \mu M)$ was studied. For this, clams $(11$ to $14 \mathrm{~mm})$ were taken from a stock which was held in coarse dune sand, receiving unfiltered flowing seawater at the Oosterschelde field station (Tidal
Water Division, Middelburg). For the experiment, the individuals were held in polyethylene acid washed beakers, $7 \mathrm{~cm}$ from the bottom on a net, tightened between a polyvinyl chloride ring. Water was gently stirred with a magnetic stirrer. The individuals were allowed to acclimatize to the laboratory conditions for $3 \mathrm{~d}$. Temperature was held constant at $6^{\circ} \mathrm{C}$.

\section{Results}

\section{${ }^{64} \mathrm{Cu}$ uptake by photoplankton (Expt 1$)$}

In Fig. $1 \mathrm{~A}$ a typical example of the adsorption of ${ }^{64} \mathrm{Cu}$ on Phaeodactylum tricornutum is given. The high concentration on the algae in the first measurement (after a few minutes) showed that very fast uptake occurred immediately after the introduction of ${ }^{64} \mathrm{Cu}$. After this initial high uptake, the concentration on the algae increased slowly. Within $3.45 \mathrm{~h}$, average adsorption into the algae was $3270 \pm 870 \mathrm{cpm} \mathrm{ml}^{-1}$. During the following $24 \mathrm{~h}$, adsorption increased to $6290 \pm 960$. Initial concentration in the water was $35990 \pm 870 \mathrm{cpm} \mathrm{ml}^{-1}$. After $28 \mathrm{~h}$, the concentration was $29900 \pm 1710 \mathrm{cpm}$. At this time, $17.5 \%$ of the initial activity in the water was adsorbed into the algae. Refreshing the seawater after $1 \mathrm{~d}$ (Fig. $1 \mathrm{~B}$ ) did not result in an increased concentration in the algae, although the dissolved ${ }^{64} \mathrm{Cu}$ concentration in the water was elevated. The reason for this was a considerable loss of algae during the refreshing procedure (note the logscale!).

The algae, as treated in Fig. $1 \mathrm{~A}$, were centrifuged after $28 \mathrm{~h}$, washed with EDTA and FSW and resuspended in ${ }^{64} \mathrm{Cu}$-free FSW. The decrease of total ${ }^{64} \mathrm{Cu}$ associated with algae in Fig. $1 \mathrm{~A}$ was due to the loss of algae during centrifugation and the loss of loosely adsorbed ${ }^{64} \mathrm{Cu}$. After the resuspension in ${ }^{64} \mathrm{Cu}$-free $\mathrm{FSW}$, the algae lost ${ }^{64} \mathrm{Cu}$ immediately, with a resulting higher ${ }^{64} \mathrm{Cu}$ concentration in the water than in the algae. This effect was shown in all spiking treatments, irrespective of the duration of the washing periods with EDTA and seawater. In our experiments, however, leaking of tracer to the dissolved phase was not desirable, as the ultimate goal was to separate the two pathways of tracer uptake. Because redistribution of ${ }^{64} \mathrm{Cu}$ in the system could not be prevented, EDTA was used as a complexing agent to prevent leached ${ }^{64} \mathrm{Cu}$ from being taken up by bivalves, feeding on the algae.

\section{Complexation of ${ }^{64} \mathrm{Cu}$ by EDTA (Expt 2)}

In Fig. $2 \mathrm{~A}$, the adsorption of ${ }^{64} \mathrm{Cu}$ onto shells introduced together with ${ }^{64} \mathrm{Cu}$ and EDTA addition, is presented. The sorption process on the shell was comparable with a situation without EDTA (Fig. 2B). Measurements after $20 \mathrm{~h}$ indicated no further adsorption on the shell, suggesting an equilibrium situation. The ${ }^{64} \mathrm{Cu}$ concentration in the water had decreased considerably as a result of adsorption to the wall and the shells. The decrease was described best with an exponential curve and amounted to $55 \%$ of the original concentration after $24 \mathrm{~h}$.

If shells were introduced after equilibrium of the seawater with ${ }^{64} \mathrm{Cu}$ and EDTA for at least $20 \mathrm{~h}$, sorption 
$\mathrm{cpm} / \mathrm{ml}$

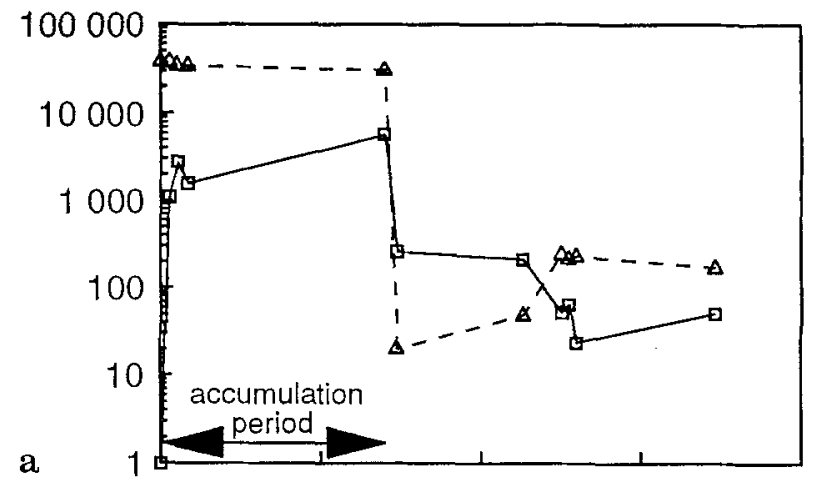

$\mathrm{cpm} / \mathrm{ml}$

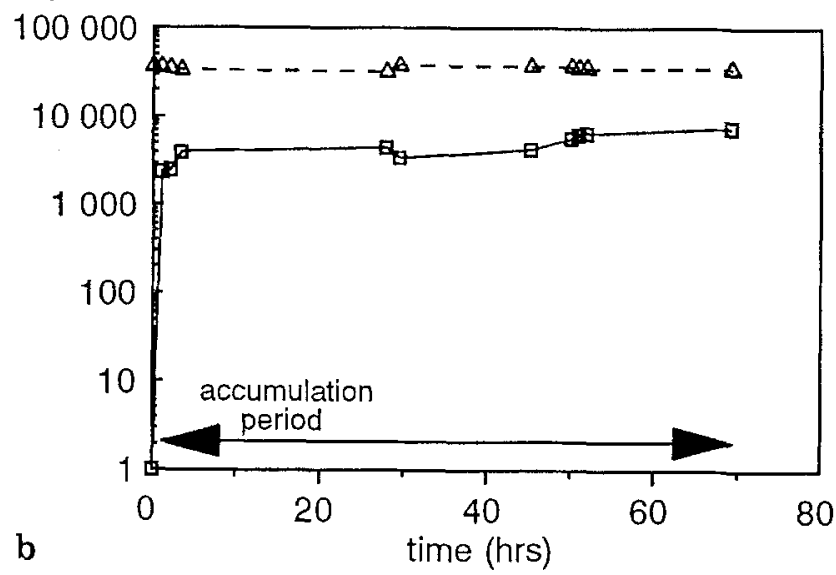

Fig. 1. Phaeodactylum tricomutum. (A) Accumulation and elimination of ${ }^{64} \mathrm{Cu}$ by $P$. tricornutum. Accumulation period was $28 \mathrm{~h}$. At $t=28 \mathrm{~h}$, the algae were concentrated and resuspended in ${ }^{64} \mathrm{Cu}$-free filtered seawater. ${ }^{64} \mathrm{Cu}$ in seawater $(\Delta) ;{ }^{64} \mathrm{Cu}$ in algae (口). (B) Accumulation of ${ }^{64} \mathrm{Cu}$ by $P$. tricornutum. Accumulation period was $72 \mathrm{~h}$. At $t=28 \mathrm{~h}$, the algae were concentrated and resuspended in a fresh ${ }^{64} \mathrm{Cu}$ solution. ${ }^{64} \mathrm{Cu}$ in seawater $(\Delta) ;{ }^{64} \mathrm{Cu}$ in algae (ㅁ)

occurred at a very low rate. This indicated that in this situation, ${ }^{64} \mathrm{Cu}$ was complexed by EDTA for the most part (Fig. $2 \mathrm{~A}$ ).

Mixing ${ }^{64} \mathrm{Cu}(310 \mathrm{nM})$ and EDTA together before introduction in the seawater resulted in a lower sorption rate (Fig. 2C). This effect was demonstrated at a 31 as well as at a $310 \mathrm{n} M{ }^{64} \mathrm{Cu}$ solution. Shells that were introduced after $24 \mathrm{~h}$ now showed a low adsorption rate, indicating that the concentration of uncomplexed ${ }^{64} \mathrm{Cu}$ had remained relatively constant during this period.

From these experiments it could be concluded that adding EDTA was effective, but only after at least $20 \mathrm{~h}$ equilibration time, or when EDTA-and ${ }^{64} \mathrm{Cu}$ were mixed before being added. However, in a feeding experiment, $20 \mathrm{~h}$ equilibration would take too long. Moreover, mixing of ${ }^{64} \mathrm{Cu}$ and EDTA in advance was not possible, as the ${ }^{64} \mathrm{Cu}$ was being released from the algae during the experiment. Immediate complexation by EDTA was desirable. Therefore, the sorption kinetics experiments were repeated with an EDTA concentration 100 times higher (Fig. 3 A).

In this situation, sorption onto shells was reduced to less than $0.5 \%$ compared with the situation without
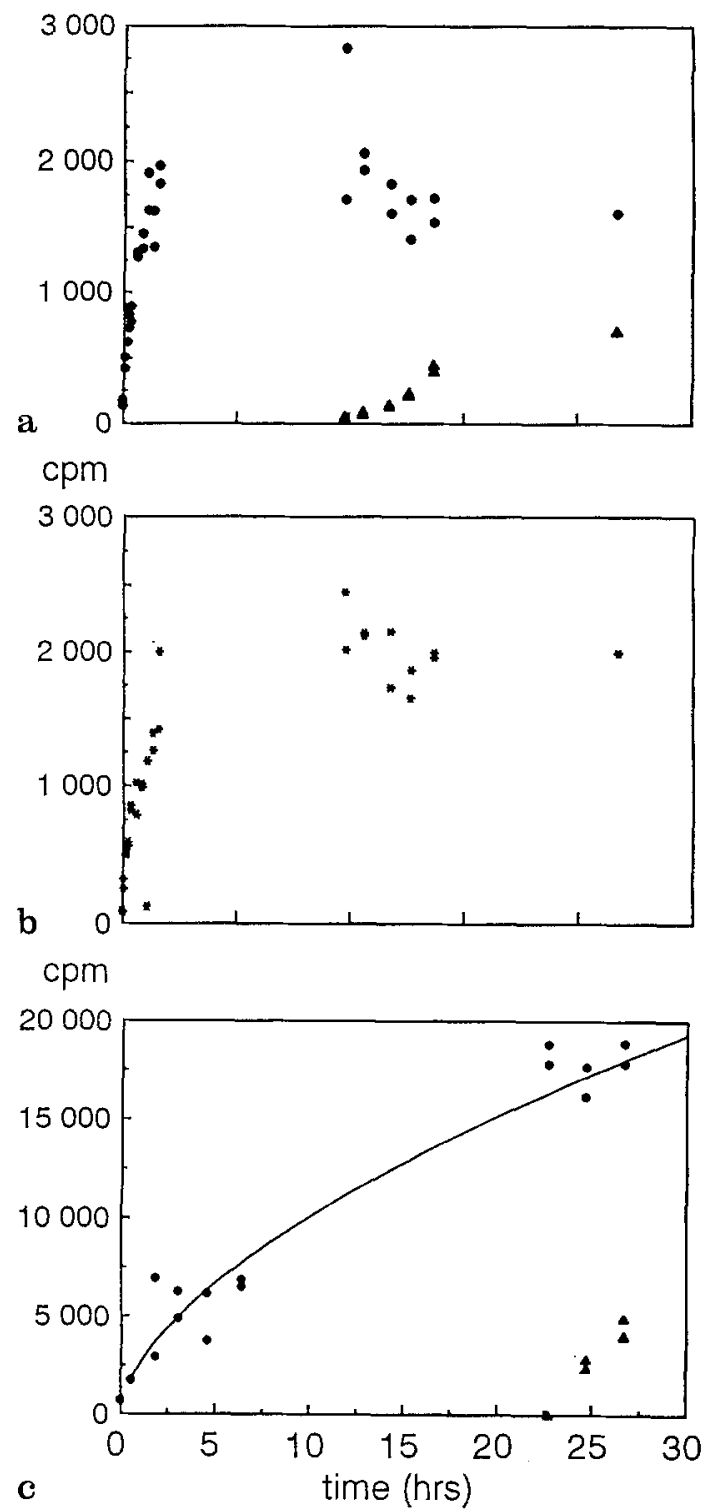

Fig. 2. Macoma balthica. Adsorption of ${ }^{64} \mathrm{Cu}$ on shells. (A) $31 \mathrm{n} M$ ${ }^{64} \mathrm{Cu}+2.7 \mu M$ EDTA. Immediate adsorption (EDTA and ${ }^{64} \mathrm{Cu}$ not mixed in advance) (•). Adsorption when shells were introduced to the seawater after a 20 -h equilibration time (4). (B) $31 \mathrm{nM}{ }^{64} \mathrm{Cu}$ without EDTA. (C) $310 \mathrm{n} M{ }^{64} \mathrm{Cu}+2.7 \mu M$ EDTA mixed together before introduction to the seawater. Adsorption on shells introduced at the outset $(\bullet)$. Adsorption when shells were introduced after $23 \mathrm{~h}$ equilibration time (A)

EDTA. Uptake by Macoma balthica appeared to be reduced to about $1 \%$ of the uptake without EDTA (Fig. 3B). In the situation without EDTA, shell adsorption was at least three times higher than tissue uptake.

\section{Discussion and conclusion}

With the algal spiking procedure, the problem of ${ }^{64} \mathrm{Cu}$ leaking from the labelled algae occurred, irrespective of any algal washing period (Expt 1). Gutknecht (1963) observed a similar loss of ${ }^{65} \mathrm{Zn}$ from marine benthic algae and Rice and Willis (1959) observed this with ${ }^{144} \mathrm{Ce}$ from marine planktonic algae. Because the redistribution of 
$\mathrm{cpm}$
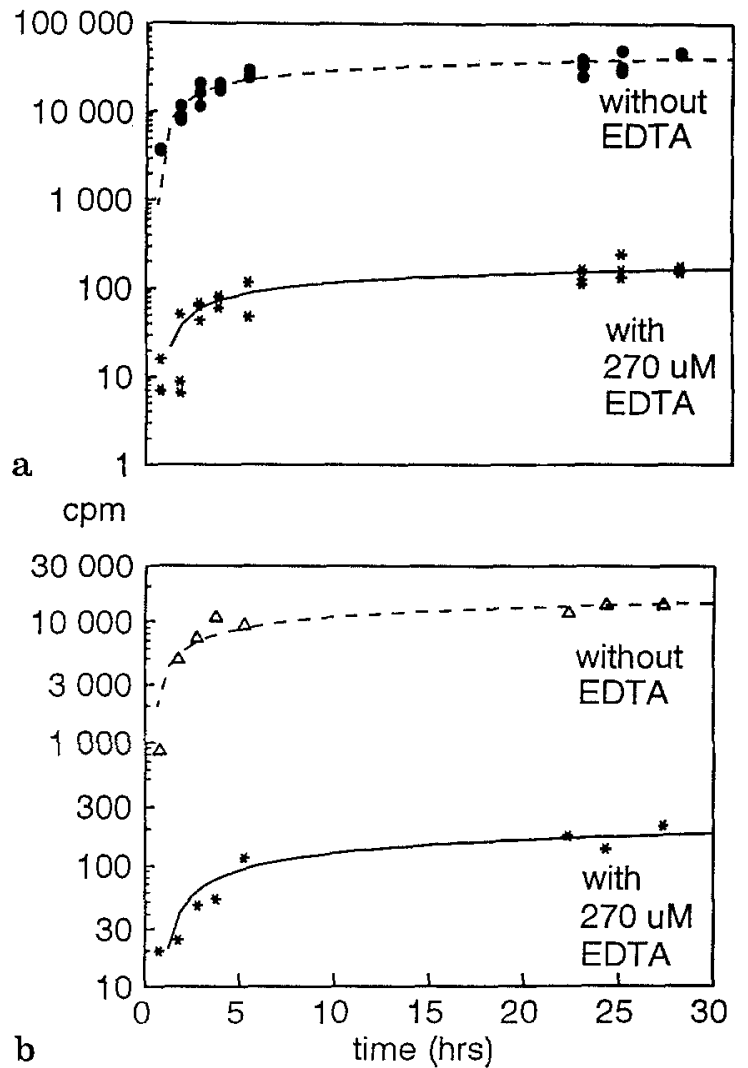

Fig. 3. Macoma balthica. (A) Adsorption of ${ }^{64} \mathrm{Cu}$ with and without $270 \mu M$ EDTA onto shells and (B) accumulation in tissue. ${ }^{64} \mathrm{Cu}$ concentration was $310 \mathrm{n} M$

Table 1. Added and theoretical concentrations of dissolved and complexed copper and EDTA. Theoretical concentrations calculated with the help of the computer program SOILCHEM

\begin{tabular}{lllllll}
\hline Added & \multicolumn{5}{c}{ Calculated } \\
\cline { 1 - 3 } \cline { 5 - 7 } $\begin{array}{lllllll}\mathrm{Cu} \\
\left(\mu \mathrm{g} 1^{-1}\right)\end{array}$ & $\begin{array}{l}\mathrm{Cu} \\
(\mu M)\end{array}$ & $\begin{array}{l}\text { EDTA } \\
(\mu M)\end{array}$ & & $\begin{array}{l}\text { Cu-free } \\
(\mu M)\end{array}$ & $\begin{array}{l}\text { EDTA-free } \\
(\mu M)\end{array}$ & $\begin{array}{l}\text { Ca-free } \\
(\mathrm{m} M)\end{array}$ \\
\hline 1 & 0.016 & 27 & $3.3 \times 10^{-9}$ & $2.5 \times 10^{-7}$ & 3.94 \\
2 & 0.032 & & 0.0041 & & 3.94 \\
2 & 0.032 & 2.7 & $4.38 \times 10^{-7}$ & $3.46 \times 10^{-10}$ & 3.94 \\
20 & 0.32 & 2.7 & $4.92 \times 10^{-6}$ & $3.07 \times 10^{-10}$ & 3.94 \\
5 & 0.079 & 0.027 & 0.0069 & $1.8 \times 10^{-14}$ & 3.94 \\
5 & 0.079 & 0.27 & $2.1 \times 10^{-5}$ & $1.8 \times 10^{-11}$ & 3.94 \\
5 & 0.079 & 2.7 & $1.1 \times 10^{-6}$ & $3.4 \times 10^{-10}$ & 3.94 \\
5 & 0.079 & 270 & $9.9 \times 10^{-9}$ & $3.8 \times 10^{-8}$ & 3.85 \\
\hline
\end{tabular}

${ }^{64} \mathrm{Cu}$ in feeding experiments is undesirable, we used EDTA to prevent dissolved ${ }^{64} \mathrm{Cu}$ from being accumulated. In Expt 2, it was noticed that although sufficient EDTA was available in theory (see Table 1), the results indicated that EDTA was not totally efficient in complexing $\mathrm{Cu}$ immediately. This can be explained by the fact that in seawater competition with other cations that are available in much higher concentrations (mainly calcium and magnesium) interferes with the Cu-EDTA complexation. As the conditional equilibrium constant of the $\mathrm{Cu}$ -
EDTA complex is higher than the other complexes, $\mathrm{Cu}$ will ultimately displace the other cations. The displacement by $\mathrm{Cu}$ takes hours (Morel et al. 1979), whereas the figures, computed with SOILCHEM, have an equilibrium situation as a starting point. Fortunately, an excess amount of EDTA came up to our expectations. No direct harmful effects of this excess EDTA on the algae were expected, as the free concentration of major ions like calcium was hardly influenced (Table 1). However, it remains doubtful whether algae are able to grow further with this amount of EDTA, because essential elements like $\mathrm{Zn}, \mathrm{Fe}$ and $\mathrm{Mn}$ are complexed for more than $99 \%$.

In conclusion, the aim of the present study was to design an experimental setup that would make it possible to measure uptake of particulate $\mathrm{Cu}$ without the interference of dissolved $\mathrm{Cu}$. In conventional experiments with spiked algae (or any other food source), redistribution of Cu takes place, complicating the assessment of a separate route to the overall $\mathrm{Cu}$ uptake. The tendency of dissolved $\mathrm{Cu}$ to form strong EDTA complexes that are hardly biologically available makes it possible to separate the uptake routes. Because the complexation of $\mathrm{Cu}$ by EDTA is a slow process in seawater, it is necessary to use an excess amount of EDTA. By minimizing the uptake of dissolved ${ }^{64} \mathrm{Cu}$ through complexation, it is possible to study the uptake of ${ }^{64} \mathrm{Cu}$ associated with algae by aquatic organisms that feed on the algae. Details on uptake experiments with ${ }^{64} \mathrm{Cu}$-labelled algae are described in a second communication (Absil et al. 1994).

Acknowledgements. We thank A. Hannewijk from the Jacobahaven field station for providing the Macoma balthica, K. de Rooy for maintaining the Phaeodactylum tricornutum culture and M. Senden from the Interfaculty Reactor Institute who carried out the SOILCHEM calculations. We thank L. J. A. Gerringa, J. W. Rijstenbil and Prof. J.H. Koeman for their comments on earlier drafts of the manuscript.

\section{References}

Absil, M. C. P., Wolterbeek, H. T., Kroon, K. (1994). Availability of copper from phytoplankton and water for the bivalve $\mathrm{Maco}$ ma balthica. II. Uptake and elimination from ${ }^{64} \mathrm{Cu}$-labelled diatoms and water. Mar. Biol. 118: 129-135

Bentley-Mowat, J. A., Reid, S. M. (1977). Survival of marine phytoplankton in high concentrations of heavy metals, and uptake of copper. J. exp. mar. Biol. Ecol. 26: 249-264

Borchardt, T. (1985). Relationships between carbon and cadmium uptake in Mytilus edulis. Mar. Biol. 85: 233-244

Cheng, T. C. (1979). Use of copper as a molluscicide. In: Nriagu, J. O. (ed.) Copper in the environment, Vol II. Health effects. Wiley-Interscience, New York, p. 401-432

Crecelius, E. A., Hardy, J. T., Gibson, C. I., Schmidt, R. L., Apts, C. W., Gurtisen, J. M., Joyce, S. P. (1982). Copper bioavailability to marine bivalves and shrimp: relationship to cupric ion activity. Mar. envirl Res. 6: 13-26

Fisher, N. S., Bjerregaard, P., Fowler, S. W. (1983). Interactions of marine phytoplankton with transuranic elements. I. Biokinetics of neptunium, plutonium, americium, and californium in phytoplankton. Limnol. Oceanogr. 28 (3): 432-447

Gerringa, L. J. A., van der Meer, J., Cauwet, G. (1991). Complexation of copper and nickel in the dissolved phase of marine sediment slurries. Mar. Chem. 36: $51-70$

Gutknecht, J. (1963). ${ }^{65} \mathrm{Zn}$ uptake by benthic marine algae. Limnol. Oceanogr. 8: $31-38$ 
Morel, F. M. M., Morel, N. M. L., Anderson, D. M., McKnight, D. M., Rueter, J. G. (1979). Trace metal speciation and toxicity in phytoplankton cultures. In: Sakin Jacoff, F. (ed.) Advances in marine research. U.S. EPA Environ. Res. Lab., Narragansett (Rhode Island), p. 38-61

Rice, T. R., Willis, V. M. (1959). Uptake, accumulation and loss of radioactive cerium-144 by marine planktonic algae. Limnol. Oceanogr. 4: 277-290

Riisgård, H. U., Bjørnestad, E., Møhlenberg, F. (1987). Accumulation of cadminm in the mussel Mytilus edulis: kinetics and importance of uptake via food and sea water. Mar. Biol. 96: $349-353$

Sposito, G., Cobes, J. (1988). Soilchem: a computer program for calculation of chemical speciation in soils. Kerney Foundation of Soil Sciences, University of California, Berkeley, California
Stephenson, R. R., Taylor, D. (1975). The influence of EDTA on the mortality and burrowing activity of the clam Venerupis decussata exposed to sublethal concentrations of copper. Bull. envir. Contam. Toxic. 14: $304-308$

Sundra, W. G., Klaveness, D., Palambo, A. V. (1984). Bioassays of cupric ion activity and copper complexation. In: Kramer, C. J. M., Duinker, J. C., Martinus Nijhoff, W. (eds.) Complexation of trace metals in natural waters. Junk Publishers, The Hague, p. 393-410

Zamuda, C. D., Sunda, W. G. (1982). Bioavailability of dissolved copper to the American oyster Crassostrea virginica. I. Importance of chemical speciation. Mar. Biol. 66: 77-82

Communicated by O. Kinne, Oldendorf/Luhe 